\title{
PREVALENCE OF FELINE INFLUENZA VIRUS INFECTION IN CAT IN MYMENSINGH AND CHAPAI NAWABGONJ DISTRICTS OF BANGLADESH
}

\author{
M. E. Alam, M. S. Rahman*, R. R. Sarker, A. Nahar, S. U. Bhuiyan, M. A. S. Sarker, S. K. Dey ${ }^{1}$ and M. A. H. \\ N. A. $\operatorname{Khan}^{1}$ \\ Department of Medicine, ${ }^{1}$ Department of Pathology, Faculty of Veterinary Science, Bangladesh Agricultural \\ University, Mymensingh-2202, Bangladesh
}

\begin{abstract}
The study was conducted to determine the prevalence of Feline influenza virus (FInV) infection in cat in Chapai Nawabgonj and Mymensingh district of Bangladesh during October, 2011 to April, 2012. A total of 122 nasal swab samples were collected randomly from cats of selected areas and questionnaire based data on location, ownership status, age, season and health status of cat were recorded. The test was performed by commercial rapid RapiGen ${ }^{\circledR}$ Feline influenza Ag Test kit following the manufacturer's (RapiGen Inc., korea) instructions. Overall prevalence of FInV infection was recorded $3.28 \%$ where $2.53 \%$ in Mymensingh (Mymensingh sadar) and $4.65 \%$ in Chapai Nawabgonj (Bholahat) district. The prevalence was $3.45 \%$ in unowned cat and $2.86 \%$ in owned cat. The prevalence was $3.75 \%$ in $<1$ year's age group, $5.00 \%$ in $>7$ year's age group and no positive case found in 1-7 year's age group. The prevalence was $4.48 \%$ in winter season, $3.03 \%$ in summer season and no positive case was found in rainy season. The prevalence was $18.18 \%$ in sick cat and no positive case was found in apparently healthy cat. No statistically significant relationship was found in relation to location, ownership status, age, season and health status of cat. More study is needed to know the detail epidemiology of this disease in cat population in Bangladesh.
\end{abstract}

Key words: Feline Influenza virus, Cat, RapiGen ${ }^{\circledR}$ Feline influenza Ag Test kit, Bangladesh

\section{INTRODUCTION}

Feline Influenza Virus (Influenza type A) infects humans, other mammals and birds, and causes all flu pandemics (Wikipedia, 2012). Its ability to cross the species barrier without prior adaptation and to infect many mammal species including humans has raised concerns about a new influenza pandemic (Subbarao et al., 1998; Vahlenkamp and Harder, 2006). Influenza type A has been long absent from the list of infectious diseases considered as possibilities in dogs and cats. With the discovery that avian influenza H5N1 can infect cats and dogs, small animal veterinarians have an important role to play in detection of influenza virus strains that may become zoonotic (Beeler, 2009). As dogs and cats are in close contact with humans, it should be of greater concern as an intermediate host for avian influenza $\mathrm{A}$ in which there is the potential for viral adaptation and reassortment (Thongratsakul et al., 2010). Besides, influenza type A especially highly pathogenic avian influenza (HPAI) viruses of the $\mathrm{H} 5$ and $\mathrm{H} 7$ subtype pose a major public health threat due to their capacity to cross the species barrier and infect mammals, for example dogs, cats and humans (Rigoni et al., 2010) resulting in interspecies transmission (Thongratsakul et al., 2010). Therefore this type of infected cat is a major risk in terms of the transmission of highly pathogenic avian influenza virus of the subtype H5N1 (HPAIV H5N1) causing high mortality in poultry (World Health Organization, 2007). In cats and tigers, the clinical signs are fever, decreased activity, protrusion of the nictitating membrane, conjunctivitis and laboured breathing (Kuiken et al., 2004). Serosanguinuous nasal discharge and icterus in case of diffuse haemorrhagic lesions can be observed (Rimmelzwaan et al., 2006). In severely affected cats, sudden deaths may occur as soon as 2 days after the onset of illness (Songserm et al., 2006). Nervous signs including convulsions and ataxia are consistent with the brain lesions (Songserm et al., 2006). Acute respiratory signs caused by severe pulmonary changes and pleural effusion are among the main features (Thanawongnuwech et al., 2005, Rimmelzwaan et al., 2006). Subclinical infections also occur (Marschall and Hartmann, 2008). The property of this virus to infect and kill mammals in addition to birds (Govorkova et al., 2005) became particularly conspicuous during outbreaks in Thailand with many fatalities amongst tigers, domestic cats and other felids (Kuiken et al., 2006). Human H3N2 influenza A virus infections have occurred in dogs and cats in recent years in Japan (Said et al., 2011). Although cats had been considered resistant to disease from influenza virus infection, domestic cats and large felids are now known to be naturally und experimentally susceptible to infection with highly pathogenic avian influenza virus H5N1 (Marschall and Hartmann, 2008). Experimental infection with a HPAI H5N1 virus isolated from a human case produced a highly lethal disease in cats (Kuiken et al., 2004; Rimmelzwaan et al., 2006).

\footnotetext{
*Corresponding e-mail address: prithu102@yahoo.co.uk 


\section{E. Alam and others}

The H5N1 viruses that infected a domestic cat and dog are highly pathogenic avian influenza viruses that are virulent in mammalian species, potentially indicating transmission of $\mathrm{H} 5 \mathrm{~N} 1$ viruses from domestic animals to humans (Amonsin et al., 2007)). Cats cannot only be infected by direct or indirect contact with infected birds (Songserm et al., 2006, Leschnik et al.,2007); the virus can also be transmitted horizontally from cat to cat (Kuiken et al., 2004, Thanawongnuwech et al., 2005). Experts, therefore, think that cats might play a role in the epidemiology of HPAIV H5N1 (Kuiken et al., 2004, 2006; Songserm et al., 2006). Although Influenza A virus was detected by haemagglutination inhibition assay, immunohistochemistry and real-time RT-PCR (rRT-PCR) (Fiorentini et al., 2011) but these methods are always considered as time consuming and expensive compared to that of RapiGen ${ }^{\circledR}$ Feline Influenza Virus Antigen (FInV Ag) test. Quick diagnosis of Influenza A virus especially $\mathrm{H} 5 \mathrm{~N} 1$ infection in cats is important because of the zoonotic and pandemic potential of this virus (Marschall et al., 2008). A comparatively less expensive but rapid and confirmatory test for detection of viruses is crucial for adaptation of effective control of the disease in the developing country like Bangladesh. Considering above points, RapiGen ${ }^{\circledR}$ FInV Ag test was selected for detection of feline influenza virus in cat. Although information on prevalence of feline viral diseases are available elsewhere in the world (Addie et al., 1998) but to the best of my knowledge there is no reports on feline influenza virus (influenza virus type A) in cats in Bangladesh. So the present research was undertaken to know the prevalence of Feline influenza virus infection in local domestic cats of some selected areas of Mymensingh and chapai-Nawabgonj district in Bangladesh by using RapiGen ${ }^{\circledR}$ FInV Ag test kit.

\section{MATERIALS AND METHODS}

The study was conducted in the Department of Medicine, Faculty of Veterinary science in Bangladesh Agricultural University, Mymensingh during the period from October, 2011 to April, 2012. The samples were collected randomly from Bholahat upazilla of Chapai Nawabgonj district and Mymensingh Sadar upazilla of Mymensingh district of Bangladesh. A total of 122 cat's nasal samples were collected where 79 collected from Mymensingh and 43 from Chapai Nawabgonj district, 87 were unowned cat and 35 were owned cat. Questionnaire based data on location, ownership status, age, season and health status of cat were recorded from cat owner.

\section{Collection of sample}

Collection of samples was performed by wearing Personal Protective Equipment (PPE) like gloves, masks and protective gown along with proper disinfection of the clothing and other appliances. The nasal swabs samples were taken from randomly selected cats in study area. At first the cat was controlled properly either by holding or introducing in iron cage. The swab was collected carefully by using cotton stick. After collection, the nasal swab was placed in the buffer containing plastic vial and sometimes nasal swab (in the plastic buffer vial) was carried by the ice box to the laboratory.

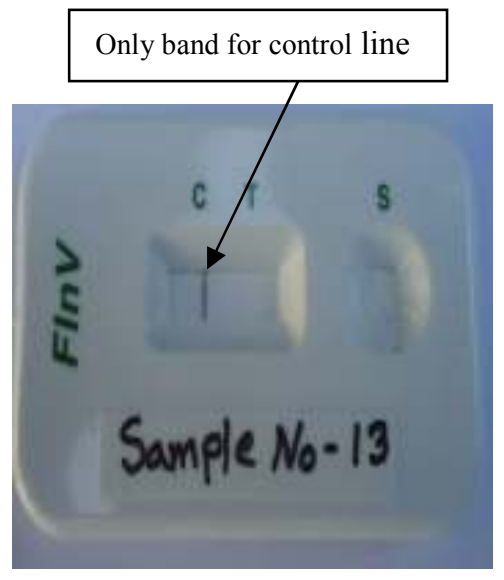

Figure 1: Single band indicating FInV infection negative

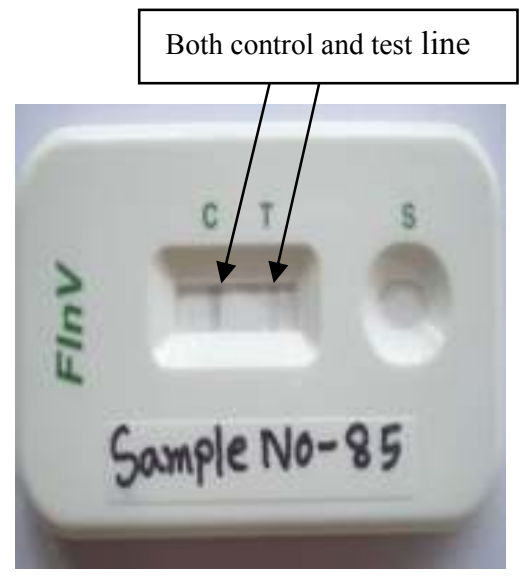

Figure 2: Double band indicating FInV infection positive 


\section{RapiGen ${ }^{\circledR}$ Feline influenza Ag Test kit method}

The test procedure was performed using RapiGen ${ }^{\circledR}$ FInV Ag test kit to detect avian influenza type A in cat according to manufacturer's (RapiGen Inc., Korea,) instruction. After collection, the stick (swab) was inserted into the bottle and securely dissolved the top portion onto the base adjusting the stick (swab) to make the length suitable to bottle. The cap of bottle was covered and agitated for 10 seconds by shaking vigorously to ensure good sample extraction. Then the mixed sample with buffer was taken by a dropper. Three drops were dispensed into the sample well (s) by squeezing the dropper and then the result was read after 5 10 minutes.

\section{Interpretation of the results}

If the red/purple band appears in the control line (c) with no apparent band in the test line (T), the sample was considered negative for Avian Influenza A Virus in cat (Fig 1). If two red/purple bands appeared one in the control line (C) and the other in the test line (T), the sample was considered positive for the presence of Avian Influenza A Virus in cat (Fig 2).

\section{Data processing and statistical analysis}

The data was entered in Microsoft Excel 2007 and transferred to R.14.2 (The R foundation for Statistical Computing, Vienna, Austria) for descriptive and analytical statistics. Bivariable logistic regression method was used to determine any association between area, type of cat, season, and age cat with Feline influenza virus infection in R.

\section{RESULTS AND DISCUSSION}

A total of 122 nasal swab samples were collected from cats of two districts in Bangladesh. The samples were tested for the presence of Feline influenza virus infection in cat. Out of 122 swab samples, 4 showed positive reaction to RapiGen ${ }^{\circledR} F I n V$ Ag test kit. So the overall prevalence of FInV infection in cat at Mymensingh Sadar upazilla in Mymensingh district and Bholahat Upazilla in Chapai Nawabgonj district was 3.28\% (Table 1).

Table 1. Overall prevalence of Feline influenza virus (FInV) infection in cat of Mymensingh and Chapai Nawabgonj district

\begin{tabular}{|ccc|}
\hline Sample tested & No of positive cases & Prevalence (\%) \\
\hline 122 & 4 & 3.28 \\
\hline
\end{tabular}

The prevalence is lower than the prevalence of FInV (5\%) reported by Islam et al. (2012). The present finding is much more lower than the overall sero-prevalence of FInV (Avian Influenza A), 21.8\% at Louisiana, Minnesota and Madison in United state of America reported by McCullers et al. (2010) and 22.5\% at Ohio in United state of America reported by Ali et al. (2011). The prevalence of FInV is higher in these studies because they conducted study on serum sample but the present study was conducted on nasal sample.

Among 122 cats, 79 were collected from Mymensingh district and 43 from Chapai Nawabgonjdistrict. 2 cases were found positive among 79 cats in Mymensingh district and prevalence was $2.53 \%$ and another 2 positive cases were found in 43 cats in Chapai Nawabgonj district and prevalence was $4.65 \%$. The prevalence of FInV was higher in Chapai Nawabgonj district than Mymensingh district but statistically it was insignificant (Table 2). This is due to more contact of cat with poultry species in Bolarhat Upazila than Mymensingh sadar because Bholahat is a rural area and people rearing more poultry species than Mymensingh sadar upazilla which is a city area and people rearing less poultry species.

Out of 87 unowned cats, 3 cases were positive and out of 35 owned cats, 1 case was positive. So the prevalence of FInV infection was $3.45 \%$ and $2.86 \%$ in unowned cat and owned cat, respectively (Table 2). The prevalence of Feline influenza virus in un-owned cat was higher than owned cat in both Mymensingh and Chapai Nawabgonj district. The finding is similar with the finding of Islam et al. (2012) who reported higher prevalence of FInV $(8.33 \%)$ in unowned cat than in owned cat $(4.17 \%)$. The prevalence of FInV in unowned cat was higher due to more contact with avian species than owned cat.

The age of cat was divided into three group that was $<1$ years, 1-7years and $>7$ years. 3 positive cases in 80 cats of $<1$ years old, 1 positive case in 20 cats of $>7$ years old and no positive case in 22 cats of 1-7 years old were found. The prevalence of FInV infection was 3.75\% in $<1$ years age group, $5.00 \%$ in $>7$ years age group and no positive was found in 1-7years age group (Table 2). Feline influenza virus infection was higher in kitten and older cats due to less immunity of body. 


\section{E. Alam and others}

These results can be comparable with the result of Islam et al. (2012) who reported prevalence of FInV 13.33\% in 2 months to 1 year age group, $5.88 \%$ in $>1$ year age group and no positive case in $<2$ months age group of age of cats.

Table 2. Prevalence of Feline influenza virus (FInV) infection in cat of Mymensingh and Chapai Nawabgonj district according to the factors related to cats

\begin{tabular}{|cccc|}
\hline Factors & $\begin{array}{c}\text { No. of sample } \\
\text { collected }\end{array}$ & $\begin{array}{c}\text { No. of } \\
\text { Positive cases }\end{array}$ & $\begin{array}{c}\text { Prevalence } \\
(\%)\end{array}$ \\
\hline $\begin{array}{c}\text { Location } \\
\text { Mymensingh (sadar) }\end{array}$ & 79 & 2 & 2.53 \\
Chapai Nawabgonj (Bholahat) & 43 & 2 & 4.65 \\
Ownership status & & & 3.45 \\
Un-owned & 87 & 3 & 2.86 \\
Owned & 35 & 1 & 3.75 \\
Age (years) & & & 0.00 \\
<1 & 80 & 3 & 5.00 \\
1-7 & 22 & 0 & 0.00 \\
Seasons $\quad 20$ & 1 & 4.48 \\
Rainy* & & & 3.03 \\
Winter* & 22 & 0 & 18.18 \\
Summer* & 67 & 3 & 0.00 \\
Sick & 33 & 1 & \\
Health status of cat & & 4 & \\
Apparently healthy & 22 & 0 & \\
\hline
\end{tabular}

*Rainy season=July-October, *Winter Season=November-February, ${ }^{*}$ Summer Season=March-June

Among 122 samples; 22, 67 and 33 samples were collected during rainy, winter and summer season, respectively. 3 positive cases during winter, 1 positive case during summer and no positive case were found during rainy season. The prevalence of FInV was $4.48 \%$ in winter season, $3.03 \%$ in summer season and there was no positive case found in rainy season (Table 2). The prevalence of FInV in cat was higher in winter season due to lower humidity that helps to longer survival period of virus and close contact of animal.

All the 4 positive cases were found in 22 sick cats and no positive case was found in 100 apparently healthy cats. On the basis of health status the prevalence of Feline influenza virus infection was $18.18 \%$ in sick cat with clinical sign of conjunctivitis and labored breathing and no positive case was found in apparently healthy cat (Table 2). The finding is dissimilar with the finding of Islam et al. (2012) who reported higher prevalence in apparently healthy cats $(5.13 \%)$ than prevalence in sick cats $(4.17 \%)$. Increase prevalence in sick cat in present study may be due to increase virus execration by nasal secretion in cat with these clinical signs. Presence of Feline influenza virus in cat is very sensitive matter because the virus have zoonotic property. Beeler (2009) stated that avian influenza $\mathrm{H} 5 \mathrm{~N} 1$ can infect cats and dogs, and the appearance of canine influenza H3N8, small animal veterinarians have an important role to play in detection of influenza virus strains that may become zoonotic. This study is very important to us due to zoonotic potentialities of this virus and people of Bangladesh is more frequently contact with cat

\section{REFERENCES}

1. Addie DD, Toth S, Thomson H, Greenwood N and Jarret JO (1998). Detection of feline parvovirus in dying pedigree kittens. Veterinary Record 142: 353-356.

2. Ali A, Daniels JB, Zhang Y, Rodriguez-Palacios A, Hayes-Ozello K, Mathes L and Lee CW (2011). Pandemic and seasonal human influenza virus infections in domestic cats: prevalence, association with respiratory disease, and seasonality patterns. Journal of Clinical Microbiology 49(12): 4101-4105. 
3. Amonsin A, Songserm T, Chutinimitkul S, Jam-On R, Sae-Heng N, Pariyothorn N, Payungporn S, Theamboonlers A and Poovorawan Y (2007). Genetic analysis of influenza A virus (H5N1) derived from domestic cat and dog in Thailand. Archives of Virology 152(10): 1925-1933.

4. Beeler E (2009). Influenza in dogs and cats. Veterinary Clinics of North America: Small Animal Practice39(2): 251-264.

5. Fiorentini L, Taddei R, Moreno A, Gelmetti D, Barbieri I, De Marco MA, Tosi G, Cordioli P and Massi P (2011). Influenza A pandemic (H1N1) 2011 virus outbreak in a cat colony in Italy. Zoonoses and Public Health58(8): 573-81.

6. Govorkova EA, Rehg JE, Kraus S, Yen HL, Guan Y, Peiris M, Nguyen TD, Hahn TH, Puthavathana P, Long HT, Buranathai C, Lim W, Webster R and Hoffmann E (2005). Lethality to ferrets of H5N1 influenza viruses isolated from humans and poultry in 2004. Journal of Virology 79: 2191-2198.

7. Islam MA, Rahman MS, Rony SA, Uddin MJ, Rahman AKMA, Islam MT and Islam MA (2012). Survey of Feline Influenza and Feline Leukemia Virus Infection in Local Breed Cats of Bangladesh. International Journal of Tropical Medicine 7: 98-102.

8. Kuiken T, Fouchier R, Rimmelzwaan G, Osterhaus A and Roeder P (2006). Feline friend or potential foe? Nature 440: 741-742.

9. Kuiken T, Rimmelzwaan G, van Riel D, van Amerongen G, Baars M and Fouchier R (2004). Avian H5N1 influenza in cats. Science 306: 241.

10. Leschnik M, Weikel J, Mo“ stl K, Revilla-Ferna'ndez S, Wodak E, Bago' Z, Vanek E, Benetka V, Hess MT and halhammer JG (2007). Subclinical infection with avian influenza A (H5N1) virus in cats. Emerging Infectious Diseases 13: 243-247.

11. Marschall J and Hartmann K (2008). Avian influenza A H5N1 infections in cats. Journal of Feline Medicine Surgery 10(4): 359-365.

12. Marschall J, Schulz B and Hartmann K (2008). Evaluation of a point-of-care influenza antigen test for the detection of highly pathogenic avian influenza H5N1 virus in cats. Transboundary Emerging Disease 55(7): 315-317.

13. McCullers JA, Van De Velde LA, Schultz RD, Mitchell CG, Halford CR, Boyd KL and Schultz-Cherry $\mathrm{S}(2010)$. Seroprevalence of seasonal and pandemic influenza A viruses in domestic cats. Archives of Virology 156(1): 117-120.

14. Rigoni M, Toffan A, Viale E, Mancin M, Cilloni F, Bertoli E, Salomon A, Marciano S, Milani A, Zecchin B, Capua I and Cattoli G (2010). The mouse model is suitable for the study of viral factors governing transmission and pathogenesis of highly pathogenic avian influenza (HPAI) viruses in mammals. Veterinary Research 41(5): 66.

15. Rimmelzwaan GF, van Riel D, Baars Ms, Bestebroer TM, van Amerongen G and Fouchier RAM (2006). Influenza A virus (H5N1) infection in cats causes systemic disease with potential novel routes of virus spread within and between hosts. American Journal of Pathology 168: 176-183.

16. Amonsin A, Songserm T, Chutinimitkul S, Jam-On R, Sae-Heng N, Pariyothorn N, Payungporn S, Theamboonlers A and Poovorawan Y (2007). Genetic analysis of influenza A virus (H5N1) derived from domestic cat and dog in Thailand. Archives of Virology 152(10): 1925-1933.

17. Beeler E (2009). Influenza in dogs and cats. Veterinary Clinics of North America: Small Animal Practice39(2): 251-264.

18. Fiorentini L, Taddei R, Moreno A, Gelmetti D, Barbieri I, De Marco MA, Tosi G, Cordioli P and Massi P (2011). Influenza A pandemic (H1N1) 2011 virus outbreak in a cat colony in Italy. Zoonoses and Public Health 58(8): 573-81.

19. Govorkova EA, Rehg JE, Kraus S, Yen HL, Guan Y, Peiris M, Nguyen TD, Hahn TH, Puthavathana P, Long HT, Buranathai C, Lim W, Webster R and Hoffmann E (2005). Lethality to ferrets of H5N1 influenza viruses isolated from humans and poultry in 2004. Journal of Virology 79: 2191-2198.

20. Islam MA, Rahman MS, Rony SA, Uddin MJ, Rahman AKMA, Islam MT and Islam MA (2012). Survey of Feline Influenza and Feline Leukemia Virus Infection in Local Breed Cats of Bangladesh. International Journal of Tropical Medicine 7: 98-102.

21. Kuiken T, Fouchier R, Rimmelzwaan G, Osterhaus A and Roeder P (2006). Feline friend or potential foe? Nature 440: 741-742. 


\section{E. Alam and others}

22. Kuiken T, Rimmelzwaan G, van Riel D, van Amerongen G, Baars M and Fouchier R (2004). Avian H5N1 influenza in cats. Science 306: 241.

23. Leschnik M, Weikel J, Mo“ stl K, Revilla-Ferna'ndez S, Wodak E, Bago' Z, Vanek E, Benetka V, Hess MT and halhammer JG (2007). Subclinical infection with avian influenza A (H5N1) virus in cats. Emerging Infectious Diseases 13: 243-247.

24. Marschall J and Hartmann K (2008). Avian influenza A H5N1 infections in cats. Journal of Feline Medicine Surgery 10(4): 359-365.

25. Marschall J, Schulz B and Hartmann K (2008). Evaluation of a point-of-care influenza antigen test for the detection of highly pathogenic avian influenza H5N1 virus in cats. Transboundary Emerging Disease 55(7): 315-317.

26. McCullers JA, Van De Velde LA, Schultz RD, Mitchell CG, Halford CR, Boyd KL and Schultz-Cherry S (2010). Seroprevalence of seasonal and pandemic influenza A viruses in domestic cats. Archives of Virology 156(1): 117-120.

27. Rigoni M, Toffan A, Viale E, Mancin M, Cilloni F, Bertoli E, Salomon A, Marciano S, Milani A, Zecchin B, Capua I and Cattoli G (2010). The mouse model is suitable for the study of viral factors governing transmission and pathogenesis of highly pathogenic avian influenza (HPAI) viruses in mammals. Veterinary Research 41(5): 66.

28. Rimmelzwaan GF, van Riel D, Baars Ms, Bestebroer TM, van Amerongen G and Fouchier RAM (2006). Influenza A virus (H5N1) infection in cats causes systemic disease with potential novel routes of virus spread within and between hosts. American Journal of Pathology 168: 176-183.

29. Said AW, Usui T, Shinya K, Ono E, Ito T, Hikasa Y, Matsuu A, Takeuchi T, Sugiyama A, Nishii N and Yamaguchi T (2011). A sero-survey of subtype H3 influenza A virus infection in dogs and cats in Japan. Journal of Veterinary Medicine Science 73(4): 541-544.

30. Songserm T, Amonsin A, Jam-On R, Sae-Heng, N, Pariyothorn N, Payungporn S, Theamboonlers A, Chutinimitkul S, Thanawongnuwech R and Poovorawan Y (2006). Fatal avian influenza A H5N1 in a dog. Emerging Infectious Disease 12: 1744-1747.

31. Subbarao K, Klimov A, Katz J, Regnery H, Lim W, Hall H, Perdue M, Swayne D, Bender C, Huang J, Hemphill M, Rowe T, Shaw M, Xu X, Fukuda K and Cox N (1998). Characterization of an avian influenza A (H5N1) virus isolated from a child with a fatal respiratory illness. Science 279: 393-396.

32. Thanawongnuwech R, Amonsin A, Tantilertcharoen R, Damrongwatanapokin S, Theamboonlers A and Payungporn S (2005). Probable tiger-to-tiger transmission of avian influenza H5N1. Emerging Infectious Disease 11: 699-701.

33. Thongratsakul S, Suzuki Y, Hiramatsu H, Sakpuaram T, Sirinarumitr T, Poolkhet C, Moonjit P, Yodsheewan $\mathrm{R}$ and Songserm T (2010). Avian and human influenza A virus receptors in trachea and lung of animals. Asian Pacific Journal of Allergy and Immunology 28(4): 294-301.

34. Vahlenkamp TW and Harder TC (2006). Influenza virus infections in mammals. Berliner und Muenchener tieraerztliche Wochenschrift 119: 123-131.

35. Wikipedia(2012). Orthomyxoviridae. http://en.wikipedia. org/ wiki/ Influenza_virus.

36. World Health Organization (2007). Areas reporting confirmed occurrence of $\bar{H} 5 \mathrm{~N} 1$ avian influenza in poultry and wildbirds since 2003. Available at: http://gamapserver. who.int/mapLibrary/Files /Maps/Global_ SubNat_H5N1 in Animal Confirmed CUMULATIVE_20070717.png 